\title{
Forced Convection Solar Dryer System
}

\author{
Aditya Chaudhari ${ }^{1}$, Avinash Patil ${ }^{2}$, Sagar Patil ${ }^{3}$, Shubham Sagare ${ }^{4}$, Pravin.S.Patil ${ }^{5}$ \\ 1,2,3,4 UG Student, Department of Mechanical Engineering, GF'S Godavari College of Engineering Jalgaon 425003, India, \\ ${ }^{5}$ Assistant Professor, Department of Mechanical Engineering, GF'S Godavari College of Engineering Jalgaon425003
}

Received on: 16 July, 2021

Revised on: 17 August, 2021

Published on: 19 August, 2021

\begin{abstract}
This paper presents the design and construction of a solar dryer for drying agriculture product such as banana. In many countries of the world, the use of solar thermal systems in the agricultural area to conserve vegetables, fruits, coffee and other crops has shown to be practical, economical and the responsible approach environmentally. Solar heating systems to dry food and other crops can improve the quality of the product, while reducing wasted produce.Under the module of Advance topics in mechanical engineering projects.
\end{abstract}

Keywords- Solar Heating System, Solar Dryer System

\section{I -INTRODUCTION}

$\mathrm{D}_{\mathrm{r}}$ ying is a process of dehydration of food products which means reducing the moisture content from the food to improve its shelf life by preventing bacterial growth.we have introduced a high efficiency low cost vegetable dryer for our advance topic in mechanical engineering module. This dryer has been designed to construct from material available in the market at low cost. This especially to over come the problems encountered in the sun drying such as many disadvantages such as spoilt products due to rain, wind, dust, insect infestation, animal attack and fungi. This dryer consists of main parts namely Solar collector, Solar chamber, Chimney, Trays.

\section{II - LITERATURE REVIEW}

[1] Bukola O. Bolaji.et.al :- Designed, constructed and tested the solar wind-ventilated cabinet dryer in Nigeria on latitude $7.5^{\circ}$ N.Comparatively, drying with the solar cabinet dryer showed better results than open air-drying. During the period of test, the average air velocity through the solar dryer was $1.62 \mathrm{~m} / \mathrm{s}$. The maximum drying air temperatures was found to be $64^{\circ} \mathrm{C}$ inside the dryer.

[2] M. Mohanraj, P. Chandrasekar :- The performance of an indirect forced convection solar drier integrated with heat storage material was designed, fabricated and investigated for chili drying. The drier with heat storage material enables to maintain consistent air temperature inside the drier. The inclusion of heat storage material also increases the drying time by about $4 \mathrm{~h}$ per day. The chili was dried from initial moisture content $72.8 \%$ to the final moisture content about $9.2 \%$ and $9.7 \%$ (wet basis) in the bottom and top trays respectively. They concluded that, forced convection solar drier is more suitable for producing high quality dried chilli for small holders.

[3] Diemuodeke E. Ogheneruona, Momoh O.L. Yusuf :Designed and fabricated direct natural convection solar dryer to dry tapioca in rural areas. A minimum of 7.56 $\mathrm{m} 2$ solar collector area is required to dry a batch of 100 $\mathrm{kg}$ tapioca in 20 hours (two days drying period).

\section{III - METHODOLOGY}

The solar food dryer is generally constructed by wood because it is easily available and light in weight and cost. Since the entire casing of wood only the top of air heater chamber is made, the major construction works of solar dryer is carpentry works. 


\section{International Journal of Innovations in Engineering and Science, www.ijies.net}

The following material is applied to make fullfill the solar dryer :

1) $12 \mathrm{~mm}$ Plywood 2) Cover sheet 3) Fevicol, adhesives 4) Waterbond solvent 5) Nails and screws 6) Net 7)12v Blowing fan 8) PVC (pipe, coupling and elbow).

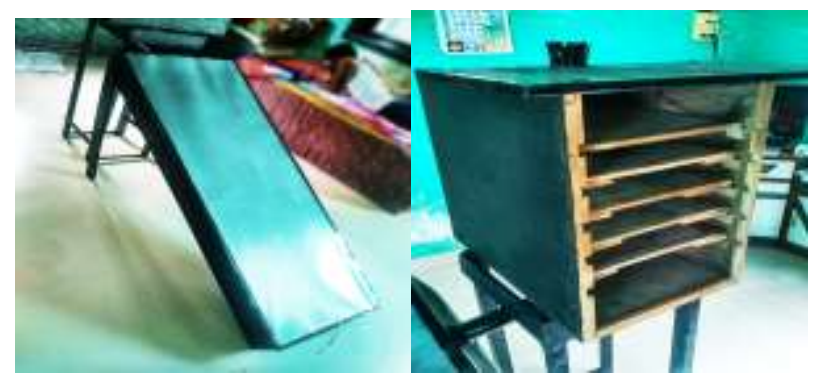

Image : 1 , Solar Collector Image : 2 , Solar Chamber

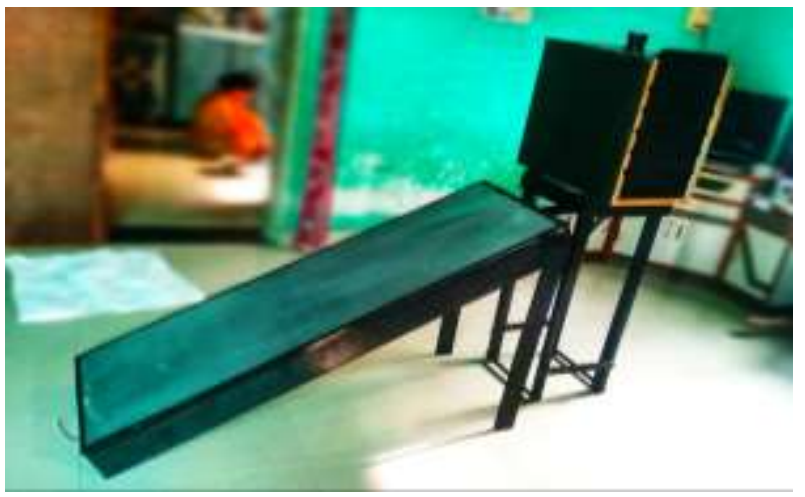

Image : 3 , Complete Assembled Solar Dryer

\section{IV - DESIGN}

Consideration - All The design is made for the optimum temperature for the dryer.T0 of $65^{\circ} \mathrm{C}$ and the air inlet temperature or the ambient temperature of dryer as $\mathrm{T} 1=35^{\circ} \mathrm{C}$. The design of the drying chamber is made as spacious as possible dimension of $20 \times 13 \times 20$ inch.

Drying Chamber, with dimension of $20 \times 60 \times 5$ inch Solar Collector at inclination of $30^{\circ}$. And the supporttable frame is the dimension of $36 \times 13$ inch. Five trays are made up of metal net. The tray dimension is $19 \times 11.5$ inch.

Calculation - Solar Collector / Air Heater Angle of Tilt $(\beta)$. It states that the angle of tilt $(\beta)$ of the air heaters

$$
\beta=10^{\circ}+\text { lat } \phi
$$

Where latitude of Jalgaon is approximately $21 \mathrm{~N}$ so angle of tilt is $31^{\circ}$ to horizontal.
Moisture contents according to the following simple formula.

$$
\text { Mc, }(w \cdot b, \%)=\left(\left(m_{i}-m_{f}\right) \div m_{i}\right) \times 100
$$

Where, $\mathrm{m}_{\mathrm{i}}$ and $\mathrm{m}_{\mathrm{f}}$ are the initial and final mass, $(\mathrm{kg})$. if moisture content within the experimental campaign were determined with two hours intensive as the represen tative samples.

\section{V - RESULT \& DISCUSSION}

The comparison of moisture content for different flow rates $(0.5,1$ and $2 \mathrm{~m} / \mathrm{s})$ over drying time. The maximum temperatures achieved with $0.5,1$ and $2 \mathrm{~m} / \mathrm{s}$ are $49.5,45$ and $41^{\circ} \mathrm{C}$, respectively, with almost similar ambientair temperature for all the velocities. At the end of 2 days of drying, i.e.16h, the moisture content in the bananas is $34.98,29.63$ and $36.04 \%$ for $0.5,1$ and $2 \mathrm{~m} / \mathrm{s}$, respectively.If the absolute moisture removal rate is considered then the moistue removal rate is fastest with the velocity of $1 \mathrm{~m} / \mathrm{s}$, followed by 0.5 and $2 \mathrm{~m} / \mathrm{s}$.

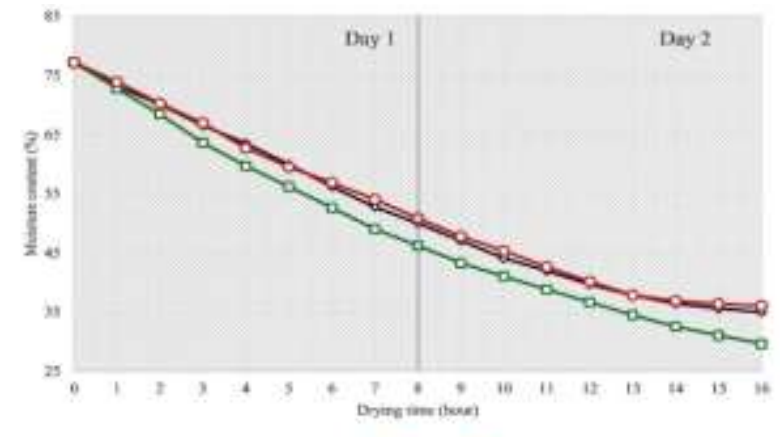

The quality of the products obtained is more important. It is noted that with velocity of $0.5 \mathrm{~m} / \mathrm{s}$, the dried banana obtained has cardboard-like structure, hard outer surface, too light and looks like not ripened which is unacceptable. Because of the faster rate of moisture removal with $0.5 \mathrm{~m} / \mathrm{s}$, the rate of evaporation increased which resulted in hardening of the surface.

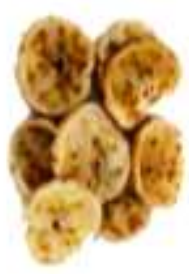

$0.5 \mathrm{~m} / \mathrm{s}$

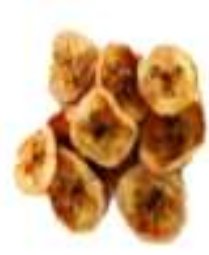

$1 \mathrm{~m} / \mathrm{s}$

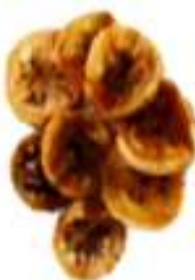

$2 \mathrm{~m} / \mathrm{s}$
Image : 4, Dried Banana Sample 
Vol. 6 , No. 10, 2021, PP. 116 - 118

International Journal of Innovations in Engineering and Science, www.ijies.net

On the other hand, the rapid cooling of the surface of banana slices due to faster air velocity with the air inlet velocity of $2 \mathrm{~m} / \mathrm{s}$ resulted in dark colour with blackening of the surface, and the surface became hard. Due which the banana obtained is of unacceptable quality.

But the banana samples obtained by drying at a velocity of $1 \mathrm{~m} / \mathrm{s}$ at the collector inlet are having more consistent quality of dried banana with good colour, texture, no dusty appearance, chewy and natural aroma. So with 1 $\mathrm{m} / \mathrm{s}$, good quality of banana can be obtained with quite high drying rates. The dried banana samples obtained with different air velocities were also compared with the dried banana samples. These also confirm that the dried banana samples obtained by a velocity of $1 \mathrm{~m} / \mathrm{s}$ are acceptable.

\section{VI - CONCLUSION}

Drying constant was found denoted fast drying processes for the forced convection against the passive. Drying system efficiency for the forced convection was higher for the first day comparing with the following days due to the fast drying in the moisture falling stage. At the end of $16 \mathrm{~h}$ of drying, about $3.1 \%$ difference in moisture content is obtained between the two configurations which is significant. The result also shows that the banana dried at flow rate velocity of $1 \mathrm{~m} / \mathrm{s}$ over the collector is of the best quality in terms of color, taste and shape. The result also shows that the banana dried at velocity of $1 \mathrm{~m} / \mathrm{s}$ over the collector is of the best quality in terms of colour, taste and shape when compared to drying at 0.5 and $2 \mathrm{~m} / \mathrm{s}$ flow rate for the same solar energy input and atmospheric conditions.

\section{REFERENCES}

[1] Bukola O. Bolaji.et.al https://www.researchgate.net/publication/266383773_Perfo rmance_Evaluation_of_a_Simple_Solar_Dryer_for_Food_ Preservation

[2] M. MOHANRAJ, P. CHANDRASEKAR

https://www.researchgate.net/publication/49593948_Perfor mance_of_a_forced_convection_solar_drier_integrated_wi th_gravel_as_heat_storage_material

[3] Diemuodeke E. OGHENERUONA, Momoh O.L. YUSUF https://www.jetir.org/papers/JETIR1905158.pdf 